Research paper/Оригинальная статья

https://doi.org/10.51176/1997-9967-2021-4-116-129

МРНТИ: 06.77.61

JEL Classification J 60, 63, 64

(cc) BY-NC 4.0

\title{
Youth Labor Market in the Framework of Social Partnership: Current State and Directions of Development
}

\author{
Rysty K. Sabirova ${ }^{1 *}$, Zhanat N. Yerniyazova ${ }^{2}$, Gulnar E. Talapbayeva ${ }^{2}$, \\ Aigul K. Masalimova ${ }^{1}$, Svetlana O. Kurmasheva ${ }^{1}$ \\ ${ }^{1}$ Kh. Dosmukhamedov Atyrau University, 1 Student str., 060011, Atyrau, Kazakhstan \\ ${ }^{2}$ Korkyt Ata Kyzylorda University, 29 Aitike bi str., Kyzylorda, Kazakhstan
}

\begin{abstract}
In any developed country, the state pays special attention to the development of human capital, which has a positive effect on the quality of life and the efficiency of the economy. Kazakhstan is no exception. The current crisis conditions point to the need to create a system of social protection for the young unemployed since the future of independent Kazakhstan depends on youth. There have been significant changes in the structure of employment in Kazakhstan. The purpose of the study was to study and make recommendations on the development of the labor market based on the opinions of young people and employers in Kazakhstan. The online survey was conducted among working, self-employed and unemployed youth of 14 regions and 3 cities, namely, Nursultan, Almaty, Shymkent, seven districts of Atyrau region (Isatay, Makhambet, Kzylkoga, Kurmangazy, Inder, Makat, Zhylyoy). The public opinion of the youth of Kazakhstan on the problems of employment, youth labor market and labor migration are studied. Within the framework of the social partnership, the theoretical foundations of labor market regulation and its mechanisms were considered, the main causes of youth unemployment are considered, recommendations for the development of the youth labor market are given. The research has scientific value, as it makes a certain contribution to the development of the youth market. Professional training and retraining of young specialists, advanced training, informing young people about vacancies in institutions, improving the digitalization of the labor market are needed among young people.
\end{abstract}

Keywords: social partnership, youth, labor market, youth unemployment, mechanisms of regulation.

For citation: Sabirova, R.K., Yerniyazova, Zh. N., Talapbayeva, G.E., Masalimova, A.K., \& Kurmasheva S.O. (2021). Youth Labor Market in the Framework of Social Partnership: Current State and Directions of Development. Economics: the Strategy and Practice, 16(4), 116-129, https://doi.org/10.51176/1997-9967-2021-4 -116-129

* Corresponding author: Rysty K. Sabirova - Head of Department, Kh. Dosmukhamedov Atyrau University, 1 Student str., 060011, Atyrau, Kazakhstan, 8(701)7266631, e-mail: sabirovarysty@mail.ru

Conflict of interests: the authors declare that there is no conflict of interest

Financial support: The study was conducted within the framework of grant funding of scientific research by The Science Committee of the Ministry of education and science of the Republic of Kazakhstan (state registration number AP08956950 "improving the system of social protection of unemployed youth in conditions of uncertainty in the Republic of Kazakhstan”).

Acknowledgments. From this point of view, we would like to express our gratitude to the committee of Science of the Ministry of education and science of the Republic of Kazakhstan, which financed the project, to our colleagues involved in the project in conducting the research, and to our Russian colleague A.V. Grigoriev, who took part in the processing of the research questionnaire

The article received: 27.10 .2021

The article approved for publication: 18.11.2021

Date of publication: 30.012 .2021 


\title{
Әлеуметтік әріптестік аясында жастар еңбек нарығы: заманауи жағдайы мен дамыту бағыттары
}

\author{
Сабирова Р.К. ${ }^{*}$, Ерниязова Ж.Н. ${ }^{2}$, Талапбаева Г.Е. ${ }^{2}$, Масалимова А.К. ${ }^{\text {, }}$ \\ Курмашева C.O. ${ }^{1}$ \\ ${ }^{1}$ «Х.Досмұхамедов атындавы Атырау университеті» КеАҚ, Студенттер к-сі, 1, \\ Атырау, 060011, Қазақ̆стан \\ ${ }^{2}$ Қорқыыт Ата атындавы Қызылорда университеті, Айтеке би к-сі, 29, Қызылорда к, Қазақсстан
}

\begin{abstract}
Түйін
Кез келген дамыған елде мемлекет өмір сүру сапасының өсуіне және елдің ұлттық экономикасының тиімділігіне қолайлы әсер ететін адами капиталды дамытуға ерекше көңіл бөледі. Қазақстан бұдан тыс қалмайды. Қазіргі дағдарыстық жағдайлар жұмыссыздарды, әсіресе, жастарды әлеуметтік қорғау жүйесін құру қажеттілігін көрсетеді, өйткені тәуелсіз және егеменді Қазақстанның болашағы жастарға байланысты. Соңғы жылдары Қазақстанда халықты жұмыспен қамту құрамы саласында да елеулі өзгерістер болды. Зерттеудің мақсаты-қазіргі заманғы Қазақстанның дамуы жағдайында әлеуметтік әріптестік шеңберінде жастардың еңбек нарығын зерттеу, жастар мен жұмыс берушілердің еңбек саласындағы пікірлерін ескере отырып, жастардың еңбек нарығын дамыту бойынша ұсыныстар беру.Бұл зерттеуде Қазақстанның 18-25 жастағы кәсіпорында жұмыспен қамтылған, өзін-өзі жұмыспен қамтыған және жұмыссыз жастар арасында онлайн сауалнама жүргізілді, ол Қазақстанның 14 облыс орталықтары мен республикалық маңызы бар 3 қаласында, атап айтқанда Нұр-Сұлтан, Алматы, Шымкент қалаларында, сонымен қатар Атырау облысының жеті аудан (Исатай, Махамбет, Қызылқоға, Құрманғазы, Индер, Мақат, Жылыой) аумағында жүргізілді. Бұл мақалада әлеуметтік әріптестік аясында еңбек нарығын реттеу мен оның тетіктерінің теориялық негіздері қарастырылды, 18 бен 28 жастағы жастар еңбек нарығына талдау жасалды, жастар жұмыссыздығының басты себептері қарастырылып, зерттеу нәтижесінде жастар жұмыссыздығын төмендету, жастардың жұмыспен қамтылуын арттыру, жастар еңбек нарығын жетілдіру бойынша ұсыныстар берілді. Зерттеудің ғылыми құндылығы жастар еңбек нарығының дамуына белгілі бір үлес қосуынан көрінеді. Жастарды жұмыспен қамтуда, жастар жұмыссыздығын азайтуда жас мамандарды кәсіптік оқыту және қайта оқыту, біліктілікті арттыру, мекемелердегі бос жұмыс орындары туралы жастарды ақпараттандыру, еңбек нарығын цифрландыруды жетілдіру қажет.
\end{abstract}

Tүйін сөздер: әлеуметтік әріптестік, жастар, еңбек нарығы, жастар жұмыссыздығы, реттеу тетіктері.

Дәйексөз алу үшін: Сабирова Р.К., Ерниязова Ж.Н., Талапбаева Г.Е., Масалимова А. К., Курмашева С.О. (2021). Әлеуметтік әріптестік аясында жастар еңбек нарығы: заманауи жағдайы мен дамыту бағыттары. Экономика: стратегия және практика, 16(4), 116-129, https://doi.org/10.51176/1997-9967-2021-4 -116-129

* Хат-хабаршы авторы: Сабирова Рысты Куандиковна - Экономика ғылымдарының кандидаты, қауымдастырылған профессор, кафедра меңгерушісі, «Х.Досмұхамедов атындағы Атырау университеті» КеАҚ, Студенттер к-сі, 1,060011, Атырау қ., Қазақстан, 8(701)7266631, e-mail: sabirovarysty@mail.ru

Мүдделер қақтығысы: авторлар мүдделер қақтығысының жоқтығын мәлімдейді.

Қаржыландыру. Зерттеу ҚР БҒМ Ғылым комитетінің ғылыми зерттеулерді гранттық қаржыландыруы шеңберінде жүргізілді (мемлекеттік тіркеу нөмірі АР08956950 “Қазақстан Республикасында белгісіздік жағдайында жұмыссыз жастарды әлеуметтік қорғау жүйесін жетілдіру”).

Алғыс айту. Осы тұрғыдан жобаны қаржыландырған ҚРБҒМ Ғылым комитетіне, зерттеуді жүргізуде жобаға қатысушы әріптестерімізге және зерттеу бойынша сауалнаманы өңдеуге қатысқан ресейлік әріптесіміз А.В.Григорьевке алғыс білдіреміз.

Мақала редакцияға түсті: 27.10.2021

Жариялау туралы шешім кабылданды: 18.11 .2021

Жарияланды: 30.12 .2021

Экономика: стратегия и практика. Т. 16, № 4, 2021 / Economics: the Strategy and Practice. Vol. 16. No 4, 2021 


\title{
Молодежный рынок труда в рамках социального партнерства: современное состояние и направления развития
}

\author{
Сабирова Р.К. ${ }^{*}$, Ерниязова Ж.Н.ㄹ, Талапбаева Г.Е. ${ }^{2,}$ Масалимова А.К. ${ }^{1}$, \\ Курмашева C.O. ${ }^{1}$ \\ ${ }^{1}$ НАО «Атырауский университет им. Х.Досмухамедова, ул. Студенческая, 1, 060011, \\ 2. Атырау, Казахстан \\ ${ }^{2}$ Кызыллординский университет им.Коркыт Ата, ул. Айтеке би, 29, г. Қызылорда, Казахстан
}

\begin{abstract}
Аннотация
В любой развитой стране государство уделяет особое внимание развитию человеческого капитала, благоприятно влияющего на рост качества жизни и эффективности национальной экономики страны. Казахстан - не исключение. Современные кризисные условия свидетельствуют о необходимости создания системы социальной защиты безработных, особенно молодежи, так как будущее независимого и суверенного Казахстана зависит именно от молодежи. За последние годы в Казахстане произошли серьезные изменения и в области состава занятости населения. Цель исследования рассмотреть молодежный рынок труда в рамках социального партнерства в условиях развития современного Казахстана, дать рекомендации по развитию молодежного рынка труда с учетом мнения молодежи и работодателей в сфере труда. В рамках данного исследования был проведен онлайн-опрос среди самозанятой и безработной молодежи Казахстана в возрасте 18-25 лет, занятой на предприятиях, который проводился в 14 областных центрах и 3 городах республиканского значения, а именно Нур-Султан, Алматы, Шымкент, а также в семи районах Атырауской области(Исатайский, Махамбетский, Кзылқогинский, Курмангазинский, Индерский, Мақатский, Жылыойский). Было изучено общественное мнение молодежи Казахстана о социальном благополучии молодежи в Казахстане: проблемы занятости, рынка труда и трудовой миграции. В рамках социального партнерства были рассмотрены теоретические основы регулирования рынка труда и его механизмы, проанализирован рынок труда молодежи, рассмотрены основные причины безработицы среди молодежи, даны рекомендации по развитию молодежного рынка труда. Исследование имеет научную ценность, так как вносит определенный вклад в развитие молодежного рынка. В обеспечении занятости молодежи, снижении молодежной безработицы необходимо профессиональное обучение и переобучение молодых специалистов, повышение квалификации, информирование молодежи о вакансиях в учреждениях, совершенствование цифровизации рынка труда.
\end{abstract}

Ключевые слова: социальное партнерство, молодежь, рынок труда, молодежная безработица, механизмы регулирования

Для цитирования: Сабирова Р.К., Ерниязова Ж.Н., Талапбаева Г. Е., Масалимова А.К., Курмашева С.О. (2021). Молодежный рынок труда в рамках социального партнерства: современное состояние и направления развития. Экономика: стратегия и практика, 16(4), 116-129, https://doi.org/10.51176/1997-9967-2021-4-116-129

* Корреспондирующий автор: Сабирова Рысты Куандиковна - кандидат экономических наук, ассоциированный профессор, заведующая кафедрой, НАО «Атырауский университет им. Х.Досмухамедова, ул. Студенческий 1,060011, г. Атырау, Казахстан, 8(701)7266631, e-mail: sabirovarysty@mail.ru

Конфликт интересов: авторы заявляют об отсутствии конфликта интересов.

Финансирование. Исследование проводилось в рамках грантового финансирования научных исследований Комитетом науки МОН РК (государственный регистрационный номер АР08956950 “совершенствование системы социальной защиты безработной молодежи в условиях неопределенности в Республике Казахстан»).

Благодарности. Выражаем благодарность Комитету науки МОН РК, профинансировавшему проект, коллегам-участникам проекта в проведении исследования и нашему российскому коллеге Григорьеву А. В., принявшему участие в обработке анкеты по исследованию.

Статья поступила в редакцию: 27.10 .2021

Принято решение о публикации: 18.11 .2021

Опубликовано: 30.12 .2021 


\section{Kipicne}

Әлеуметтік әріптестіктің жалпы стратегиясы бүгінде мынадан көрінеді: түрлі тараптардың позициялары мен мүдделеріне нұқсан келтірмей, келіссөз үрдістің артықшылықтарын қолдана отырып, әлеуметтікеңбек және саяси қатынастардың түрлі деңгейінде (республикалық, салалық, аймақтық және кәсіпорын) бірыңғай келісілген саясатты жасау.

Соңғы жылдары біздің елімізде әлеуметтік әріптестіктің құқықтық базасын қалыптастыруда бірқатар шаралар атқарылды. Дегенмен әлеуметтік әріптестіктің құқықтық қамтамасыз етілуі, әлеуметтікеңбек қатынастарын реттейтін заңнамалық актілер мен ережелердің қабылдануы орын алды, бірақ әлі де әлеуметтік әріптестік жүйесі қалыптасу кезеңінде және оны әрі қарай дамыту қажеттілігі туындайды.

Еңбек нарығының әлеуметтік әріптестік аясында жұмыспен қамтуды реттеудегі мемлекет саясатының тиімділігі туралы айту үшін біз еңбек нарығы көрсеткіштерін, соның ішінде жастар еңбек нарығын, жұмыспен қамтуда жас мамандардың, жұмыс берушілердің және мемлекеттік органдардың позицияларын зерттеуді қажет деп таптық.

Білім мен ғылым салаларын дамытумен байланысты инновациялық экономиканың қалыптасуы заманауи Қазақстанның негізгі міндеттері екендігі белгілі. «Қазақстан - 2050» Стратегиясы бойынша заманауи білім беру, мамандарды әзірлеу мен қайта дайындаудың басты бағыты сапалы білім мен кәсіби машықтандыру басым бағыттардың бірі ретінде айтылған болатын.

Зерттеудің өзектілігі белгісіздік жағдайында 18-28 жас аралығындағы жас адамдардың еңбек нарығы тетіктерін дамытудан, соның ішінде оларды жұмысқа орналастыру немесе олардың жұмысбастылығын жоғарылату, жастар кәсіпкерлігін дамыту, жастар жұмыссыздығын азайту, жастарды мемлекеттік қолдау, заманауи қазақстандық жағдайда жастардың еңбек нарығын реттеудің әлеуметтік, ұйымдастырушылық, институционалдық тетіктерін жасақтаудан көрінеді.

Жас мамандарды кәсіби даярлау сапасының, атап айтқанда, қызмет көрсету саласының экономикадағы өсіп келе жатқан қажеттіліктеріне сәйкес келмеуі кәсіби білімнің дамуына мемлекеттік және мемлекеттік емес әсердің ұтымды арақатынасын іздеуге және шешуші рөл атқаратын әлеуметтік серіктестер арасында тиімді ынтымақтастық орнатуға итермелейді.
Адами капиталды қалыптастыру, мамандардың бәсекеге қабілеттілігі мен еңбек өнімділігін арттыру, сондай-ақ мемлекеттегі жұмыссыздықты еңсеру, жұмыссыз жастарды әлеуметтік қорғау, жастар еңбек нарығын дамыту - өзекті мәселелер.

Осы өзекті проблеманы шешу жедел техникалық прогреске жедел ден қоюға, жаңа қызмет жеткізушілерімен өзара іс-қимыл жасауға және жұмыс берушілермен диалог орнатуға қабілетті кәсіптік білім берудегі әлеуметтік әріптестіктің икемді жүйесін дамыту үшін тиісті жағдайлар жасауды талап етеді [1].

Әлеуметтік әріптестік аясында жастардың ерекше жас тобын зерттеу еңбек қызметін басқару үдерісін нақты түрде көрсетеді, оған әсер ететін негізгі институционалдық тетіктерді сипаттайды [2].

Жастар - болашақтың мәңгі қозғаушысы. Сондықтан, Қазақстанның болашаққа барар жолы қазақстандық жастардың даму деңгейімен, мүмкіндіктерімен, құнды бағдарларымен, қоғамдық өмірімен тығыз байланысты. Бұл болашақтың негізі қазір қаланады. Жастарды дамыту, оларды жұмыспен қамту мен әлеуметтік қорғау бағытында жастар саясаты аясында түрлі мемлекеттік және салалық бағдарламалар бар $[3,4]$.

Елімізде 2015 жылы 9 ақпанында «Мемлекеттік жастар саясаты туралы» ҚР Заңы қабылданды. Бұл заңда жастарды жұмысқа орналастыру және жұмыспен қамту үшін жағдай жасау, жастар арасында кәсіпкерлік қызметті дамыту үшін жағдайлар жасау туралы көрсетілген. Осы заңға сәйкес жастар деп 14-29 жас аралығындағы азаматтар жатады [5].

Еліміздегі жас азаматтардың табыстылығы болашақтағы экономика мен қоғамның табысты дамуының кепілі. Сондықтан еңбек нарығындағы жастар жағдайы, олардың әлеуметтік жағдайы, жастардың әлеуметтік - еңбек қатынастарын реттеу заманауи экономикалық ғылымдағы көптеген зерттеушілердің маңызды зерттеу объектісі ретінде алынды $[6,7,8]$.

Көптеген әдебиеттерде жастар жас сипаттамасының жиынтығы негізінде, әлеуметтік жағдайының ерекшелігімен, әлеуметтік-психологиялық қасиетімен, әлеуметтікэкономикалық, мәдени даму, қоғамдағы әлеуметтену ерекшелігімен бөліп қарастыратын қоғамның әлеуметтік тобы ретінде анықталады, соның ішінде қазіргі кезеңдегі жастардың әлеуметтік-мәдени ерекшеліктеріне қатысты жастар мәселесі басты назарда [9]. 
Жастардың жұмыспен қамтылу деңгейінің жоғарылауы кез-келген мемлекеттің тұрақты экономикалық дамуының маңызды шарты болып табылады, сондықтан жастардың жұмыспен қамтылу проблемалары өзекті болып табылады, олардың шешімі қоғамның әлеуметтік-экономикалық тұрақтылығын қамтамасыз етуге тікелей әсер етеді [10].

Әлемдік тәжірибеде өзіндік ерекшеліктері бар және осы жүйелердің негізгі белгілері көрінетін жеке модельдерден тұратын еңбек нарығын реттеудің екі басым жүйесі (экономикалық либерализм жүйесі, экономикалық дирижизм жүйесі) ерекшеленеді, оны ресейлік ғалымда өз зерттеулерінде де қарастырады [11].

Шет елдердің мемлекеттік жұмыспен қамту саясаты жас азаматтарды жұмыспен қамтуға жәрдемдесу іс-шараларын әзірлеуді көздейді, оларды іске асыру нақты жағдайдың ерекшелігін ескере отырып жүзеге асырылады, жұмыссыз жастарды әлеуметтік қорғау шараларын іске асырады. ЕАЭҚ елдері пандемия кезінде жұмыстан айырылған тұрғындарға, оның ішінде жастарға бір рет төленетін төлемдерді төлеу арқылы қолдау көрсетті. Осы мәселені қазақстандық зерттеушілер қарастырып, Қазақстан, Ресей және Армения елдеріне салыстырмалы талдау жасаудың негізінде жасалған төлемнің сомасы күнкөріс минимум көлеміне барынша жақын екенін анықтаған [12].

Әлемдік экономикалық жүйенің белсенді сын-қатерлеріне жауап бере отырып, бірқатар мемлекеттер халықаралық еңбек ұйымының (XЕҰ) саясатын қолдай отырып, іске асыруда белсенді рөл жекелеген институттарға тиесілі жастардың еңбек нарығын реттеудің белгілі бір тетіктерін қолданады. Жаклин О'Рейли және т.б. зерттеушілер жастар арасындағы жұмыссыздықты түсіну еңбек нарығының икемділігіне, кәсіби дағдылар деңгейіне және жұмыс берушілердің сұранысына қатысты экономикалық саладағы өзгерістерді жанжақты қарастыруды талап етеді деген пікірде [13].

Барлық елдерде коронавирустық пандемия және оған байланысты шектеулер экономикалық қызметтің тоқтатылуына әкелді, мектептердің, кеңселердің, сауда нүктелерінің және т. б. жабылуы мемлекеттік реттеу болмаған кезде мұндай жағдай қашықтықтан жұмыспен қамтуға ауыстыруға болмайтын қызметкерлердің жаппай босатылуына әкеп соқтырды.

Біріншісі (атап айтқанда, Болгарияда, Қазақстанда, Норвегияда, Румынияда, Словенияда, АҚШ - та, Финляндияда, ОАР-да қолданылатын) - жұмыссыздық бойынша жәрдемақыларға қол жеткізуді жеңілдету, олардың мөлшері мен төлем ұзақтығын ұлғайту есебінен жұмысынан айырылған адамдарды қолдауға бағытталған. Екіншісі (Австрия, Бельгия, Ұлыбритания, Германия, Дания, Испания, Италия, Корея Республикасы, Нидерланды, Жаңа Зеландия, Түркия, Франция, Эстония, Жапония және т. б.) карантиннен шығып, экономиканың жандануына байланысты жұмысшылар өздерінің жұмыс орындарына оралуы үшін жұмыспен қамтудың барынша мүмкін сақталуына (жалақыны субсидиялау және толық емес жұмыспен қамтуды қолдау арқылы) назар аударады[14].

\section{Материалдар мен әдістер}

Әлемде болып жатқан соңғы жағдайларға сәйкес интернет-дереккөздерге сүйене отырып, пандемия жағдайында дамыған елдердегі жұмыссыз жастарға көрсетілетін әлеуметтік көмектерді көрсету тәжірибесі зерттелді. Әдеби іріктеуде коронавирустың еңбек нарығы мен жалпы экономикаға әсері туралы сарапшылардың пікірлері қарастырылды.

Зерттеу әдіснамасын әдіс ретінде немесе әртүрлі статистикалық құралдарды қолдана отырып статистикалық мәліметтерді алу үшін деректерді жинау және талдау механизмі ретінде сипаттауға болады. Сонымен қатар, әдіснаманың екі түрі бар: сандық және сапалық. Сандық тәсіл деректерді жинау және статистикалық әдістерді қолдана отырып түсіндіру мақсатында 4000 респонденттен сауалнама алу арқылы олардың пікірін білу ретінде қолданылды. Сонымен қатар, сұхбат беруші сұхбат барысында белгілі бір үлгіден дәлелдер жинау әдісі ретінде сапалы тәсіл қолданылды.

Бұл зерттеуде Қазақстанның 18-25 жастағы кәсіпорында жұмыспен қамтылған, өзін-өзі жұмыспен қамтыған және жұмыссыз жастар арасында онлайн сауалнама жүргізілді, ол Қазақстанның 14 облыс орталықтары мен республикалық маңызы бар 3 қаласында: Нұр-сұлтан, Алматы және Шымкент қалалық елді мекендерінің, сонымен қатар Атырау облысының жеті аудан аумағында 18-25 жастағы жастардың жұмыспен қамту, еңбек нарығы және еңбек көші-қоны мәселелеріне қатысты әлеуметтік хал-ахуалын анықтауда бойынша әлеуметтік зерттеу жүргізілді.

Басты мақсат - Қазақстандағы 18-25 жастағы жастардың әлеуметтік хал-ахуалы: жұмыспен қамту, еңбек нарығы және еңбек көші-қоны мәселелері туралы ҚР жастарының 
қоғамдық пікірін зерттеу. Зерттеудің іріктемелі жиынтығының жалпы көлемі төрт мың адамды құрады.

Зерттеу барысында жүргізілген онлайн сауалнама түрінде сұраудан алынған ақпаратты өңдеу әдісіне келетін болсақ, сауалнамаларды толтыру сапасын бақылағаннан кейін зерттеу деректері MS Excel пакетінде өңделді. Жабық сұрақтарда жауаптың әр нұсқасына сандық код берілді. Ашық және жартылай жабық сұрақтарда респонденттердің мәлімдемелері кейіннен сандық кодтар беріле отырып, мазмұндық принцип бойынша топтастырылды. Сауалнама сұрақтарының жиынтығы эмпирикалық деректерді талдау тақырыбының құрылымдалған моделін құрады.

Дайындалған эмпирикалық мәліметтер IBM SPSS Statistics 25 статистикалық пакетімен математикалық өңдеуден өтті. Статистикалық талдау сауалнама сұрақтарына респонденттердің жауаптарының желілік (бір өлшемді) бөлінуін талдауды және зерделенетін белгілер арасындағы байланысты екі өлшемді талдауды қамтыды.

\section{Зерттеу нәтижелері}

Жастардың еңбек нарығын реттеудің басты тетіктері -институционалдық, құқықтық, әлеуметтік, ақпараттық және экономикалық тетіктер. Осы тетіктердің ішінде институционалдық тетіктерге тоқталайық.

Біріншіден, институттардың дамыған жүйесі кәсіпорындарға жас мамандарды жалдау, ұстау және жетілдіру жағынан тиімді саясат жүргізуге мүмкіндік береді.

Екіншіден, жастардың еңбек нарығының жұмыс істеуі туралы толық ақпарат ала отырып, жұмыс берушілер еңбекке бейімдеу мен әлеуметтендірудің оңтайлы жағдайларын қалыптастыра алады.

Үшіншіден, тиімді жұмыс істейтін институттар жүйесі жас қызметкерлерді мансаптық өсу мен дамыту үшін жағдай жасауға ықпал етеді. Жас мамандардың бәсекелестік артықшылықтарын жүзеге асыру мен қалыптастыру еңбек нарығының әлеуметтік институттарының тиімді жұмысына байланысты.

Біздер жастардың жұмыспен қамтылуын реттеу тетіктерін қарастырып, өзара әрекеттесудің сызбасын бердік (сурет 1 қараңыз).

Жастар жұмыссыздығы - жастардың жалпы әлеуметтік жағдайының маңызды индикаторларының бірі. Сондай-ақ, жұмыспен қамтылу бағытында елдің дамуының белгілі бір кезеңіндегі оның бейімделу дәрежесінің көрсеткіші болып табылады.

Қазақстан Республикасы Стратегиялық жоспарлау және реформалар агенттігі Ұлттық статистика бюросының мәліметтері бойынша қарастырсақ, жастар арасында барынша қызығушылық тудыратын сала 2019 жылы көтерме және бөлшек сауда; автомобильдерді және мотоциклдерді жөндеу 365,9 мың адам. Екінші кең тараған қызмет түрі - ауыл, орман және балық шаруашылығы 241,9 мың адам, білім беру 232,7 мың адам. Өнеркәсіпте жұмыс жасайтын жастар саны - 215,1 мың адам.

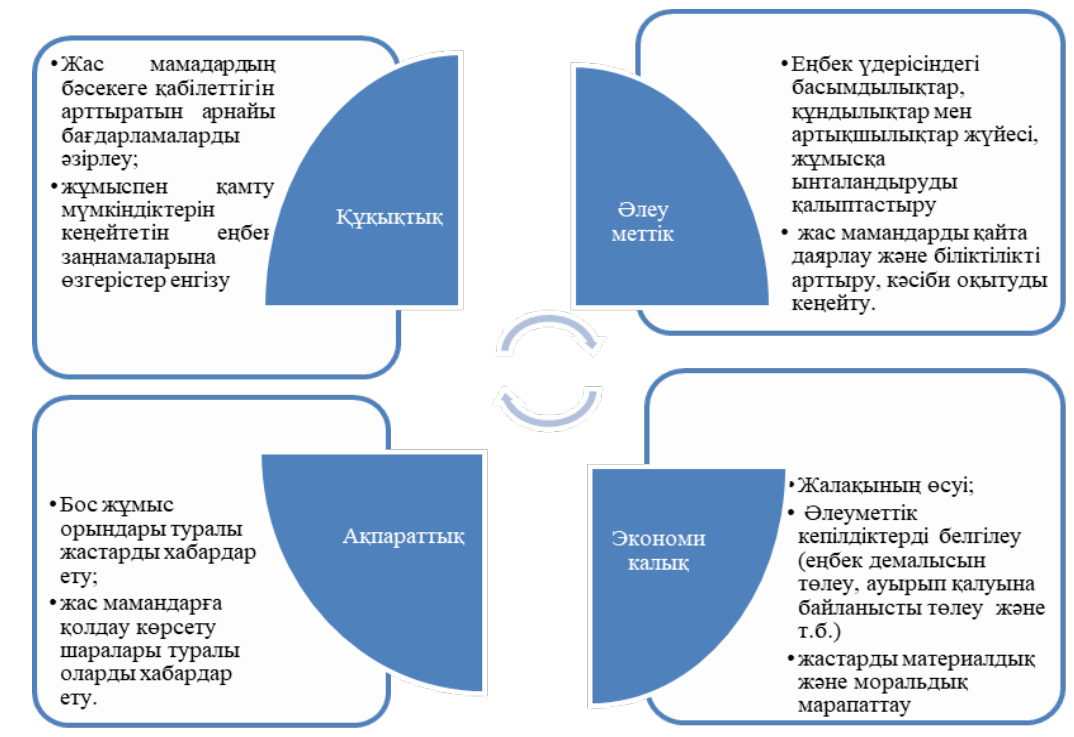

Сурет 1 - Жастардың жұмыспен қамтылуын реттеу тетіктері

Figure 1 - Mechanisms for regulating youth employment

Ескерту - Авторлармен құрастырылған

Экономика: стратегия и практика. Т. 16, № 4, 2021 / Economics: the Strategy and Practice. Vol. 16. No 4, 2021 


\section{DEMOGRAPHY, HUMAN RESOURCES AND THE LABOR MARKET}

1-кестеден жастардың экономика салалары бойынша жұмыспен қамтылуы туралы мәліметті көре отырып, 2016 жылдың I тоқсанымен салыстырғанда 2020 жылы I тоқсанда 10\%-ға азайғанын көруге болады, соның ішінде өндірістің көпшілік салаларында осы кезеңде жұмыспен қамтылған жастар саны азайған, тек көтерме және бөлшек сауда, автомобильдерді және мотоциклдерді жөндеу саласында ғана жұмыспен қамтылғандар саны артқан, демек жастар өндіріске қарағанда сауда саласында еңбек етуді қалайды.

Кесте 1 - Жастардың экономика салалары бойынша жұмыспен қамтылуы

Table 1 - Youth employment by economic sectors

\begin{tabular}{|c|c|c|c|c|c|}
\hline & \multicolumn{4}{|c|}{ Жастар (15-29 жастағы) } & \multirow[b]{2}{*}{$\begin{array}{c}\text { I тоқ } \\
2020 \text { ж. }\end{array}$} \\
\hline & $\begin{array}{c}\text { Ітоқ } \\
2016 \text { ж. }\end{array}$ & $\begin{array}{c}\text { I тоқ } \\
2017 \text { ж. }\end{array}$ & $\begin{array}{c}\text { I тоқ } \\
2018 \text { ж. }\end{array}$ & $\begin{array}{c}\text { I тоқ } \\
2019 \text { ж. }\end{array}$ & \\
\hline Экономикада жұмыспен қамтылғандар, & 2221,3 & 1968,7 & 2024,6 & 2085,2 & 2018,2 \\
\hline \multicolumn{6}{|l|}{ соның ішінде } \\
\hline Ауыл, орман және балық шаруашылығы & 323,1 & 234,9 & 286,0 & 233,6 & 241,9 \\
\hline Өнеркәсіп & 269,9 & 208,6 & 204,7 & 231,5 & 215,1 \\
\hline кен өндіру өнеркәсібі және карьерлерді қазу & 55,5 & 50,7 & 46,6 & 54,8 & 48,8 \\
\hline Өңдеу өнеркәсібі & 151,9 & 111,4 & 117,7 & 130,4 & 120,4 \\
\hline Электрмен қамтамасыз ету, газ беру & 42,3 & 32,6 & 27,8 & 28,6 & 29,7 \\
\hline $\begin{array}{l}\text { сумен жабдықтау; кәріз жүйесі, қалдықтардың } \\
\text { жиналуын және таратылуын бақылау }\end{array}$ & 20,2 & 13,9 & 12,7 & 17,6 & 16,3 \\
\hline Құрылыс & 177,8 & 159,8 & 145,6 & 153,0 & 148,3 \\
\hline $\begin{array}{l}\text { Көтерме және бөлшек сауда; автомобильдерді } \\
\text { және мотоциклдерді жөндеу }\end{array}$ & 394,3 & 346,0 & 332,4 & 401,7 & 365,9 \\
\hline Көлік және қойма & 149,6 & 131,7 & 132,3 & 139,1 & 116,6 \\
\hline Білім беру & 254,1 & 225,1 & 244,2 & 240,5 & 232,7 \\
\hline Денсаулық сақтау және әлеуметтік қызметтер & 100,2 & 109,4 & 116,4 & 99,4 & 107,3 \\
\hline Кәсіби, ғылыми және техникалық қызмет & 63,3 & 69,6 & 63,1 & 63,9 & 62,8 \\
\hline $\begin{array}{l}\text { Мемлекеттік басқару, қорғаныс, міндетті } \\
\text { әлеуметтік қамсыздандыру }\end{array}$ & 139,1 & 127,2 & 144,5 & 138,9 & 136,2 \\
\hline
\end{tabular}

2019 жылдың бірінші тоқсан соңында жұмыспен қамтылған жастар саны 2,1 млн адам болды, олардың ішінде 1,5 млн жастар жалдамалы жұмыскерлерге тиесілі, 456 мың адам - өзіндік жұмыспен қамтылғандар.

Халықты сұрау үшін зерттеу үлгісі тұрғылықты жері және жұмыспен қамтылуы сияқты әлеуметтік-демографиялық сипаттамалары көрсетілді. Қазақстанның 18-25 жастағы кәсіпорында жұмыспен қамтылған, өзін-өзі жұмыспен қамтыған және жұмыссыз жастар арасында онлайн сауалнама жүргізілді. Сауалнама онлайн түрінде өтті, оған 4000 адам қатысты. Іріктемелі жиынтықтың құрылымы 2-кестеде келтірілген.
Ең алдымен зерттеуде қолданылған таңдау жиынтығының құрылымына тоқталып өтейік. Сауалнаманы жүргізу кезеңінде сауанамаға қатысушылардың басым бөлігі (62,4\%) жұмыс жасамады; төрттен бірі (24,7\%) кәсіпорында жұмыс жасайтындықтарын атап өтсе, 12,9\% өзін - өзі жұмыспен қамтығандар есебінде болды (сурет 2).

Жұмыспен қамтылған респонденттерге «Неліктен дәл осы жұмыс орнын таңдадыңыз?» деген сұрақ қойылғанда келесі жауаптар алынды: осы жұмыс түрі өзіме ұнайды (37,8\%), осы ұжым ұнайды $(22,9 \%)$, жоғары жалақы төлейді (22,3\%), жұмыс уақыты икемді (17,6\%), осы қызметті жұмыс жасап үйреніп қалдым (14,7\%), басқа баламалы жұмыс орны табылмады (12,9\%) (сурет 3). 
Кесте 2 - Іріктемелі жиынтық құрылымы

Table 2 - Structure of the sample population

\begin{tabular}{|c|c|c|c|c|}
\hline Қазақстан өңірлері & $\begin{array}{c}\text { Кәсіпорында } \\
\text { жұмыспен } \\
\text { қамтылғандар }\end{array}$ & $\begin{array}{c}\text { Өзін-өзі } \\
\text { жұмыспен } \\
\text { қамтығандар }\end{array}$ & жұмыссыздар & Барлы ғь \\
\hline Қазақстан Республикасы & 989 & 516 & 2495 & 4000 \\
\hline Ақмола обл. ( Көкшетау қ.) & 45 & 20 & 115 & 165 \\
\hline Ақтөбе обл. (Ақтөбе қ.) & 50 & 23 & 118 & 173 \\
\hline Алматы обл. (Талдықорған қ.) & 32 & 15 & 271 & 102 \\
\hline Атырау қ. & 36 & 17 & 50 & 133 \\
\hline Жылыой ауданы & 5 & 2 & 10 & 17 \\
\hline Индер ауданы & 5 & 2 & 6 & 17 \\
\hline Исатай ауданы & 5 & 2 & 3 & 17 \\
\hline Құрманғазы ауданы & 5 & 2 & 9 & 17 \\
\hline Қызылқоға ауданы & 5 & 2 & 4 & 17 \\
\hline Мақат ауданы & 5 & 2 & 4 & 17 \\
\hline Махамбет ауданы & 5 & 2 & 5 & 17 \\
\hline Батыс Қазақстан обл. (Орал қ.) & 55 & 32 & 93 & 237 \\
\hline Жамбыл обл (Тараз қ.) & 61 & 37 & 144 & 348 \\
\hline Қарағанды обл. (Қарағанды қ.) & 61 & 37 & 170 & 348 \\
\hline Қостанай обл. (Қостанай қ.) & 56 & 32 & 137 & 228 \\
\hline Қызылорда обл. (Қызылорда қ.) & 56 & 32 & 95 & 238 \\
\hline Маңғыстау обл. (Ақтау) & 50 & 21 & 87 & 171 \\
\hline Түркістан обл. (Түркістан қ.) & 50 & 21 & 108 & 171 \\
\hline Павлодар обл. (Павлодар қ.) & 36 & 17 & 84 & 133 \\
\hline $\begin{array}{l}\text { Солтүстік Қазақстан обл. ( } \\
\text { Петропавл қ.) }\end{array}$ & 36 & 17 & 237 & 133 \\
\hline Шығыс Қазақстан обл. (Өскемен қ.) & 30 & 16 & 193 & 116 \\
\hline Нұр-Сұлтан қ. & 100 & 55 & 144 & 395 \\
\hline Алматы қ. & 100 & 55 & 283 & 395 \\
\hline Шымкент қ. & 100 & 55 & 125 & 395 \\
\hline
\end{tabular}

\section{$\%$}

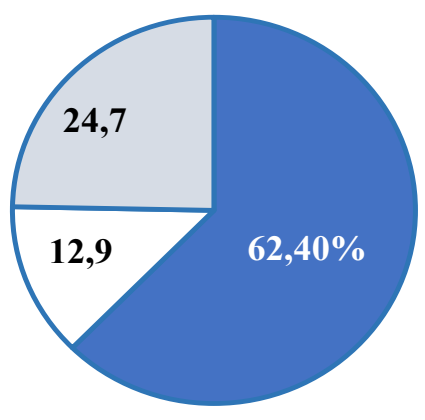

Жұмыссыздар

口Өзін-өзі жұмыспен қамтығандар

- Кәсіпорында жұмыс жасайтындар

Сурет 2 - Сауалнамаға қатысушылардың жұмыспен қамтылу жағдайы

Figure 2 - Employment status of survey participants 


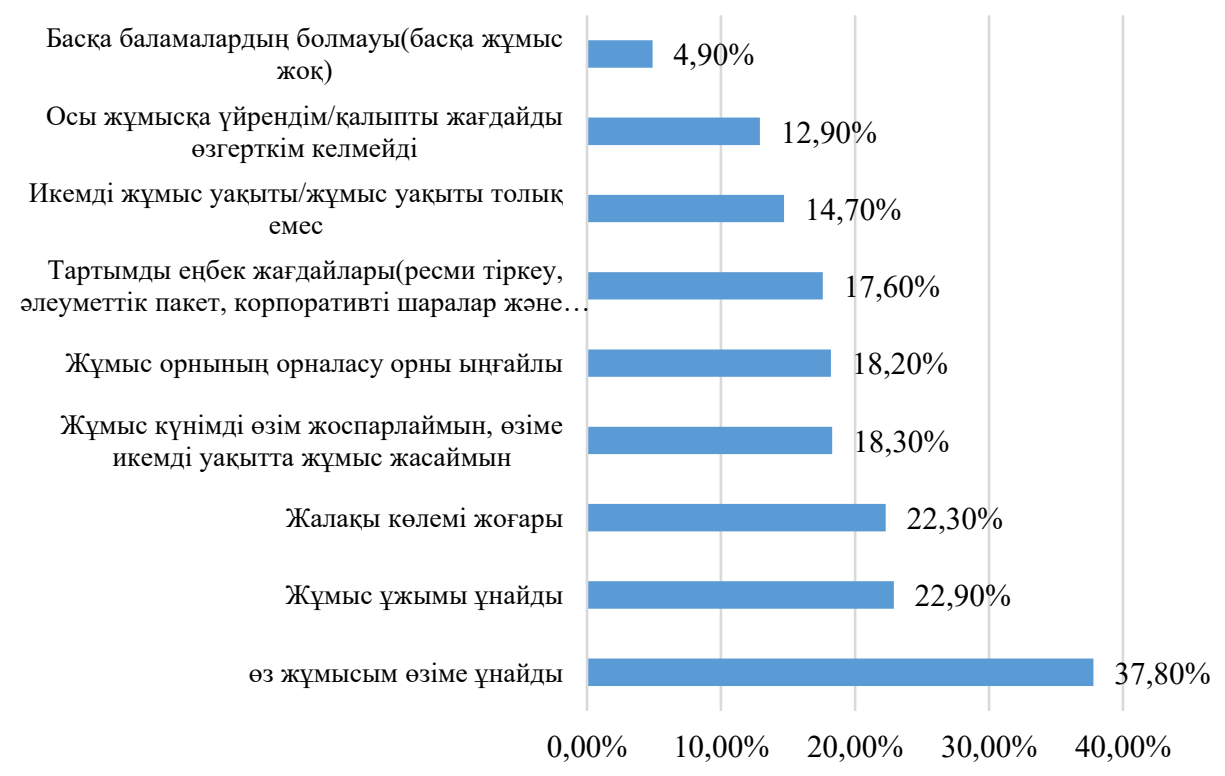

Сурет 3 - Респонденттердің сауалнама барысындағы жұмыс түрімен айналысу себептері (жұмыс жасайтын респонденттермен салыстырғанда пайызбен)

Figure 3 - Reasons for respondents to engage in the type of work during the survey (as a percentage compared to respondents who work)

Ұсынылған мәселе бойынша талдау жұмыстарын жалғастыру барысында әйелдер мен ерлер пікірлерінің ерекшеліктері салыстырылды. Алынған деректер негізінде ер адамдар әйел адамдарға қарағанда өздеріне жұмыс ұжымы ұнайтындығын, жалақы көлемі қанағаттандыратындығын, жұмыс орнына үйреніп қалғандығын атап өткен, сонымен қатар респонденттердің ішінде ер адамдар «тағы басқа» нұсқасын көбірек таңдаған. Ал әйел адамдар оларға сол жасап жатырған жұмыстарының ұнайтындығын, жұмыс орнының орналасу орны, өздеріне ыңғайлы уақытта жұмыс жасай алатындығы, сонымен қатар икемді жұмыс уақыты ұнайтындығын атап өткен. Айта кететін жағдайлардың бірі, әйел адамдар ер адамдарға қарағанда сол кездегі ұсынылып отырған жұмыс орны бойынша басқа баламалардың жоқ екендігін көрсетеді (кесте 3).

Кесте 3- Респонденттердің (әйел және ер адамдар) сауалнама барысындағы жұмыс түрімен айналысу себептері (жұмыс жасайтын респонденттермен салыстырғанда пайызбен)

Table 3-Reasons why respondents (women and men) are engaged in the type of work during the survey (as a percentage compared to working respondents)

\begin{tabular}{|l|c|c|}
\hline \multicolumn{1}{|c|}{ Сол жұмыс орнын таңдау себептері } & Ер адамдар & $\begin{array}{c}\text { Әйел } \\
\text { адамдар }\end{array}$ \\
\hline Сол жұмыс ұнайды & 19,9 & 20,3 \\
\hline Жұмыс ұжымы өте жақсы & 13,6 & 11,7 \\
\hline Жалақы көлеміне қанағаттанамын & 13,2 & 11,4 \\
\hline $\begin{array}{l}\text { Өзімнің күн тәртібімді өзім жоспарлай аламын, өзіме икемді уақытта жұмыс } \\
\text { жасаймын }\end{array}$ & 8,9 & 10,1 \\
\hline Жұмыс орнының орналасуы бойынша мекен жайы ыңғайлы & 9,3 & 9,9 \\
\hline $\begin{array}{l}\text { Еңбек жағдайлары тартымды (ресми тіркеу жұмыстары, әлеуметтік пакет, } \\
\text { корпоративтік шаралар және тағы басқалары) }\end{array}$ & 8,9 & 9,6 \\
\hline Икемді жұмыс уақыты/ толық емес жұмыс уақыты & 9,1 & 9,5 \\
\hline Осы жұмысқа үйрендім/ қалыптасқан жағдайды өзгерткім келмейді & 8,4 & 7,6 \\
\hline Басқа баламалар жоқ (басқа жұмыс жоқ) & 5,6 & 7,4 \\
\hline Басқа себептер & 3,0 & 2,5 \\
\hline
\end{tabular}


Сонымен қоса, зерттеу кезінде білім беру орындарын бітіруші түлектер мен жұмыс берушілерге интервью жүргізілді. Осы интервью қорытындысы бойынша жастардың жұмыс орындарын іздеу көздері негізінен интернет екендігі белгілі болды. Интернет арқылы жұмыс таптым деп жауап бергендер үлесі 30,2\%, сонымен қатар кадр агенттігі деп көрсеткендер үлесі де жоғары (19\%), мемлекеттік жұмыспен қамту қызметтері кадр агенттігімен салыстырғанда төмен (13\%). Ал білім беру орындарында жыл сайын өткізілетін бос орындар жәрмеңкесі сияқты арнайы шаралардың тиімділігі төмен, оның көмегімен жұмыс тапқандар саны аз (сурет 4).

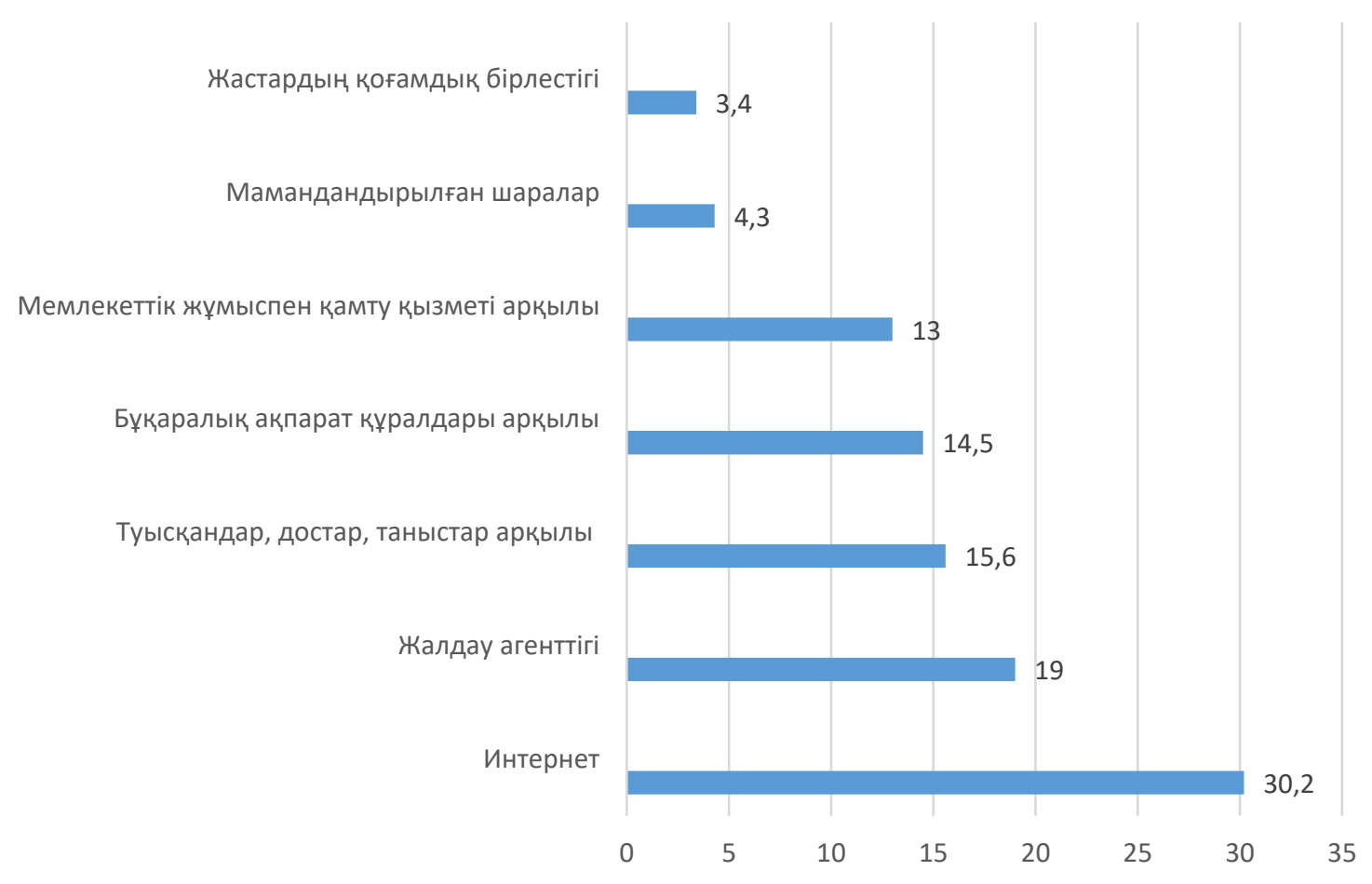

Сурет 4 - Жастардың жұмыс орындарын іздеу көздері, \%

Figure 4 - Youth Job Search sources, \%

Ескерту - Авторлармен құрастырылған.

Жас мамандарды жұмысқа алған жұмыс берушілермен сұхбаттасу арқылы жас мамандарды іздестіру мен таңдау әдістерін анықтадық. Басшылардың көпшілігі (23,3\%7) интернетте хабарландыруды орналастыру арқылы жас мамандарды жұмысқа тартқандығын айтты, ал кейбір жұмыс берушілер $(16,7 \%)$ мемлекеттік институт көмегіне жүгінгенін айтты, жұмыс берушілердің бір бөлігі (20,0\%) кадр агенттігі арқылы, жұмыс беруші өздерінің сайттарында хабарландыру жасағандығын көрсетсе (3,6\%), 2 жұмыс берушіенді бір бөлігі (6,6\% ) ЖОО түлектер жәрмеңкесінде түлектерді таңдағанын, мекемеде жұмыспен қамту орталықтарының көмегімен (10\%) жұмысқа жас мамандарды тартқанын айтады. Ал жұмыс берішінің 16,7\%-ы өз компанияларында арнайы шаралар, конкурстар өткізу арқылы жас мамандарды жұмысқа алғандығын айтты. Жұмыс берушілердің көпшілігі жастарды жұмысқа алу үшін өздері іздестіру жұмыстарын жүргізген тиімді екендігіні білдірді.

Жұмыс берушілер, жұмыс жасап жатырған жас мамандар мен жұмыс іздеп жүрген жастар арасында сауалнама жүргізу мен әңгімелесу арқасында алынған жауаптарды талдай келе, бос орындарды іздестіруде тиімді әдіс ретінде интернеттің рөлінің жоғары екендігін анықтадық.

\section{Талқылаулар мен қорытындылар}

Жұмыс берушілердің пікірінше, жастарды жұмысқа алуда келесідей мәселелерге тіреледі: жұмыс іздеушілердің іскерлік қарымқатынасының жоқтығы, сенімсіздік, білімі мен біліктілігінің талап етілетін лауазымдық міндеттерге сәйкес келмеуі, жұмыс іздеуге 
жастардың ынтасының болмауы, кәсіби және еңбек қызығушылығының белгісіздігі.

Жастардың жұмыссыз болуының негізгі себептері:

- жастарға бастапқы өтіл алу мүмкіндігінің жоқтығы;

- қазіргі жастардың жоғары жалақы төлейтін жұмысты іздеуі;

- жұмыс берушілердің жұмыс іздеген жастарға қоятын талаптарының тым жоғары болуы;

- жастардың көбісі экономика, банк ici, менеджмент, заң құқығы сияқты беделді мамандықтарды таңдауға тырысады, алайда қазақстандық еңбек нарығында мұндай мамандардың көптігінен ұсыныс сұраныстан артық.

Жастар еңбек қызметін басқаруға айтарлықтай ықпал ететін, жас қызметкерлерді іздеуге және жұмысқа орналастыруға ықпал ететін мекемелер жоқ емес, бірақ олардың жұмыстары жеткілікті түрде тиімді деп айта алмаймыз. Еңбек нарығын және талап етілетін жұмыспен қамту салаларын сипаттауда еңбек нарығы институттары туралы ақпараттың негізгі көздерін түсіну маңызды.

Мемлекеттік бағдарламалар аясында бірқатар шаралар орындалуда, атап айтқанда:

Біріншіден, білікті педагогтар, дуалдық оқыту элементтерін қолдану және түлектердің кемінде $60 \%$-ң жұмысқа орналасуы тұрғысынан оқу орталықтары мен білім беру орындарына біліктілік талаптарын күшейту;

Екіншіден, «Атамекен» Ұлттық кәсіпкерлер палатасы білім беру ұйымдарының сапалық құрамын қалыптастыруды қамтамасыз ету мақсатында оқу орталықтары мен білім саласы оқу орындарының реестрін жасауды қарастыруда.

Үшіншіден, еңбек нарығындағы сұраныстағы мамандықтар бойынша дайындау мақсатында қысқа мерзімді кәсіби оқыту үшін талап етілетін кәсіптер тізімін кеңейту мен бекіту;

Төртіншіден, жұмыс берушілерге жұмыс істеп тұрған қызметкерлерді, оның ішінде қысқартылған қызметкерлерді оқыту құнының кемінде 50\% - ын қоса қаржыландыру шартымен қайта мамандандыру мүмкіндігі беріледі [15].

Жұмыссыз жастарды жұмыспен қамтуда мемлекет мына шараларды жүзеге асыруда:

- жұмыспен қамтылмаған жастар деңгейін төмендету үшін біліктілігі жоқ тұлғаларға кәсіптік және техникалық білім алу бойынша үміткерлер санын арттыру.

- біліктілік пен дағдылар тізбесін қысқа мерзімді кәсіптік оқыту бойынша кеңейту.
- шағын несие алуда жастар үшін басым құқықты белгілеу;

- жұмыссыз жастарды кәсіпкерлікпен айналысуға ынталандыру [16].

Мемлекет тарапынан көрсетілген міндеттерді іске асыру нәтижесінде үстіміздегі жылы:

- жұмыссыздық деңгейі өспеді, оның шамасы 4,8\% -дан аспайды;

- жұмыс күшінің құрамында білімі төмен жұмыс күшінің үлесі 20\%-дан аспайды;

-еңбек ресурстарының құрамындағы өзін-өзі жұмыспен қамтамасыз еткен азаматтардың құрамында өнімсіз жұмыспен қамту үлесі 10,2\%-дан аспайды.

Зерттеу барысында жастарға жүргізілген сауалнамалар мен жұмыс берушілермен жүргізген сұхбат нәтижесінде жастар арасында жұмыссыздықтың негізгі мәселелері анықталды, олардың негізгілері:

- пандемияға байланысты өндіріс деңгейінің төмендеуі, сәйкесінше жұмыс күшіне деген сұраныстың азаюы;

- зейнетақы жүйесіндегі реформа: жастар мен егде жастар арасындағы жұмыс орны үшін бәсекенің күшеюі;

- жұмыс беруші мен жалдамалы қызметкер арасындағы жалақы бойынша келіспеушіліктер;

- мамандығы бойынша жұмысқа орналаспау;

- білікті еңбек ресурстарының шетелге кету ағымы.

Осы анықталған мәселелерді ескере келе, жастар арасындағы жұмыссыздықты жою бағыттары:

- білім жүйесіндегі модернизация: теориялық дайындық, тәжірибелік дағдыларды және ақпараттық, желілік технологияларды игеру;

- кәсіпкерлік қызмет аясында жастарды дайындау деңгейін арттыру;

- жастарды еңбек нарығындағы жаңалықтармен қамтамасыз ету, еңбек нарығын цифрландыру.

Әлеуметтік әріптестік аясында жастар еңбек нарығының теориялық және әдістемелік аспектілерін қарастыруды аяқтай отырып, мынадай қорытындыға келдік:

Біріншіден, әлеуметтік әріптестік аясында еңбек нарығының сұранысына қарай жас мамандарды даярлауды жетілдіру керек. Заманауи жағдайда мүлдем жаңа кәсіптер туындауда, алынған білім аз уақыттың ішінде ескіріп, қайта даярлауды қажет етуде. Кәсіби құзіреттілігі бар мамандарды даярлау өзекті, өйткені бұл ғаламдық трендке айналды. Жаңа мамандықтар атласы қалыптасуда. Сондықтан 
жоғары оқу орындары жаңа мамандық иелерін даярлауда сұраныс бар мамандарды даярлау бағдарламаларының қажеттілігі негізделді.

Ғаламдық технологиялық трендтер еңбек нарығын кең түрде трансформациялауға алып келеді. Сондықтан жұмыспен қамтудың жаңа нысандарын нормативтік реттеуді қайта қарау қажеттілігі туындайды.

Екіншіден, жастардың жұмыспен қамтылуын тұрақтандыру үшін жастарды жұмыспен қамтуға жәрдемдесумен айналысатын мемлекеттік қызметтердің білім беру институтымен, қоғамдық бірлестіктермен және жұмыс берушілермен байланыс болуы қажет. Бүгінде жас мамандар мен әлеуметтік институттарының белгіленген өзара іс-қимыл жүйесінің тиімділігі жеткіліксіз және жастар еңбегінің тиімділігін арттыру үшін қолайлы жағдай жасамайды. Институционалдық тетіктердің әсері қысқа мерзімді сипатқа ие, жас қызметкерлердің еңбек белсенділігін қалыптастыру бойынша жүйелі тәсіл жоқ. Еңбек нарығының әлеуметтік институттарының негіздерін дамыту және жақсарту жастардың еңбек белсенділігін тиімді қалыптастыру үшін маңызды екендігі негізделді.

Үшіншіден, жас мамандарды қолдау ретінде жастардың жұмысқа орналасуына және кәсіби тұрғыдан өзін көрсете білуіне барлық институттар өзара бірігіп әрекет ету маңызды, алайда бұл әлі де жолға қойылмаған және өте сирек жүзеге асады. Ол үшін ұйымдастырушылық қиындықтарды жеңу, сауатты ақпараттық және заңнамалық қолдау мәселелерін шешу керек.

Жұмыспен қамту орталығы, жоғары оқу орындары және жұмыс берушілер арасында жастарды жұмыспен қамту бағытында үнемі тығыз байланыс болу қажет. Жастарды жұмыспен қамтуда, жастар жұмыссыздығын азайтуда жас мамандарды кәсіптік оқыту және қайта оқыту, біліктілікті арттыру, мекемелердегі бос жұмыс орындары туралы жастарды ақпараттандыру, еңбек нарығын цифрландыруды жетілдіру қажет.

\section{Пайдаланынылван ддебиеттер тізімі}

1 Tkachenko S., Berezovska L., Protas, O., Parashchenko L., Durmanov A. (2019). Social partnership of services sector professionals in the entrepreneurship education. Journal of Entrepreneuship Education, 22(4), 1-6.

2 Кокшаров В.А., Агарков Г.А., Сущенко А.Д. (2020). Прекаризация труда как растущая форма занят ости молодых специалистов в условиях пандемии. Экономика региона, 16(4), 1061-1071. https://doi. org/10.17059/ekon.reg.2020-4-4.

3 Программа развития продуктивной занятости и массового предпринимательства на 20172021 годы, утверждена Постановлением Правительства Республики Казахстан от 29 декабря 2016 года, № 919 [Электронный ресурс]. - Режим доступа: adilet.zan.kz.

4 Государственная программа «Дорожная карта бизнеса 2020». Постановление Правительства Республики Казахстан № 301, от 13 апреля 2010 года [электронный ресурс]. - Режим доступа: adilet.zan.kz

4. «Дорожная карта бизнеса 2020». Постановление Правительства РК № 301, от 13 апреля 2010 г. [Электронный ресурс]. - Режим доступа: adilet.zan.kz.

5 «Мемлекеттік жастар саясаты туралы» ҚР Заңы. Режим доступа: https://adilet.zan.kz/kaz/docs/ Z1500000285

6 Assmann M.-L., Tolgensbakk I., Vedeler J.S., Bøhler K.K. (2020). Public employment services: building social resilience in youth? Social Policy and Administration. https://onlinelibrary.wiley.com/ doi/10.1111/spol.12649

7 Cheng G.H.-L., Chan D.K.-S., Au W.T. (2020). Profiles of employability and their career and psychological implications among unemployed youth. Applied Research in Quality of Life. https://link. springer.com/article/10.1007\%2Fs11482-020-09869-4

8 Denny-Smith G., Sunindijo R.Y., Loosemore M., Williams M., Piggott L. (2021). How construction employment can create social value and assist recovery from covid-19. Sustainability (Switzerland), 13(2), 1-20. https://doi.org/10.3390/su13020988

9 Головчин М.А., Леонидова Г.В. (2014). Социокультурные характеристики современной молодёжи: некоторые результаты пилотного исследования. Экономические и соииальные перемены: факты, тендениии, прогноз, 5 (35), pp.113-126, DOI:10.15838/esc/2014.5.35.8.

10 Сабирова Р.К., Мукашева А.Ж., Бисембиева Ж.К. (2020). Белгісіздік жағдайындағы жастардың жұмыссыздық мәселесі. Central Asian Economic Review, 5, 21-31.

11 Полищук Е.А. (2017). Институциональные практики регулирования рынка труда молодежи в зарубежных странах. Russian Journal of Entrepreneurship, 18(5), 831-848.-doi: 10.18334/ rp. $18 / 5 / 37617$

12 Сабыр Н., Әбілқайыр Н. (2021). Сравнительный анализ мер социальной поддержки населения в странах ЕАЭС в период 
глобальной пандемии. Экономика: стратегия $u$ практика, 16(1):155-163.

13 O'Reilly J., Eichhorst W., Gaboc A. (2015). Five Characteristics of Youth Unemploiment in Europe: Flexibility, Education, Migration, Family Legacies, and EU Policy, 5(1), March 23, 2015. https://doi. org/10.1177/2158244015574962

14 Синявская О.В., Горват Е.С., Грищенко Н.Б., Карева Д.Е. (2020) Обзор международного опыта в поддержке занятости и населения в условиях борьбы с пандемией коронавируса. Аналитический бюллетень НИУ ВШЭ об экономических и социальных последствиях коронавируса в России и в мире, 2, 62-74.

15. Мусина Р. (2019) Современное состояние молодежного рынка труда в Казахстане. Экономика и статистика, 1,121-126.

16 Сабирова Р.К., Мусаева А.А., Тажиденова A.P. (2021) Жастар жұмыссыздығын төмендетудегі шағын кәсіпкерліктің рөлі. Экономика: стратегия и практика, 16(1),117-129 16(1), 117-129. https://doi. org/10.51176/JESP/vol_16_issue_1_T12

\section{Reference}

1 Tkachenko, S., Berezovska, L., Protas, O., Parashchenko, L., Durmanov A. (2019). Social partnership of services sector professionals in the entrepreneurship education. Journal of Entrepreneuship Education, 22(4), 1-6.

2 Koksharov, V.A., Agarkov, G.A., Sushchenko, A.D. (2021). Precarisation of labour as a growing form of employment of young specialists in the context of the Covid-19 pandemic. Economy of Region, 16(4), 1061-1071. https://doi.org/10.17059/EKON. REG.2020-4-4 (in Russ.).

3 The program for the development of productive employment and mass entrepreneurship for 2017-2021 was approved by the Government of the Republic of Kazakhstan from December 29, 2016 No. 919 [electronic resource]. - Access mode: adilet.zan.kz. (in Russ).

4 The program "Business road map 2020". Post of the Government of the Republic of Kazakhstan No. 301 from April 13, 2010 [electronic resource], access mode: adilet.zan.kz. (in Russ).

5 Law of the Republic of Kazakhstan "on State Youth Policy". Access mode: https://adilet.zan.kz/kaz/ docs/Z15000002 (in Russ.).

6 Assmann, M.-L., Tolgensbakk, I., Vedeler, J.S., Bøhler, K.K. (2020). Public employment services: building social resilience in youth? Social Policy and Administration. https://onlinelibrary.wiley.com/ doi/10.1111/spol.12649

7 Cheng, G.H.-L., Chan, D.K.-S., Au, W.T. (2020). Profiles of employability and their career and psychological implications among unemployed youth. Applied Research in Quality of Life. https://link. springer.com/article/10.1007\%2Fs11482-020-09869-4

8 Denny-Smith, G., Sunindijo, R.Y., Loosemore, M., Williams M., Piggott L. (2021). How construction employment can create social value and assist recovery from covid-19. Sustainability (Switzerland), 13(2), 1-20. https://doi.org/10.3390/su13020988

9 Golovchin, M., Leonidova, G.V. (2014). Socio-cultural characteristics of the modern youth: some results of the pilot study, Economic and social changes facts trends forecast, 5(35), DOI:10.15838/ esc/2014.5.35.8(in Russ.).

10 Sabirova, R.K., Mukasheva,A.Zh., Bisembieva, Zh.K.(2020) The problem of youth unemployment in a state of uncertainty. Central Asian Economic Review, 5, 21-31. (in Kaz.)

11 Polishchuk, E.A.(2017). Institutional practices of regulating the youth labor market in foreign countries. Russian Journal of Entrepreneurship 18(5):831C.832848 DOI:10.18334/rp.18.5.37617(In Russ.)

12 Sabyr, N.S., Abilkaiyr, N.A.(2021). Comparative experience of social support for the population in the context of the EAEU during the global pandemic. Economics: the strategy and practice, 16(1):155-163. (In Russ.)

13 O'Reilly, J., Eichhorst, W., Gaboc, A. et.all. (2015). Five Characteristics of Youth Unemploiment in Europe: Flexibility, Education, Migration, Family Legacies, and EU Policy, 5(1), March 23, 2015. https:// doi.org/10.1177/2158244015574962

14 Sinjavskaja, O.V., Gorvat, E.S., Grishhenko, N.B., Kareva, D.E. (2020). Review of international experience in supporting employment and the population in the fight against the coronavirus pandemic. HSE Analytical Bulletin on the economic and social consequences of coronavirus in Russia and in the world, 2, 62-74. (in Russ).

15 Musina, R. (2019) The current state of the youth labor market in Kazakhstan. Jekonomika i statistika, 1,121-126. (in Russ).

16 Sabirova, R.K., Musaeva, A.A., Tazhidenova, A.R. (2021) The role of small businesses in reducing youth unemployment. Jekonomika:strategija i praktika, 16(1), 117-129. https://doi.org/10.51176/JESP/(in Kaz.) 
*Rysty K. Sabirova - Candidate of Economic Sciences, Associate Professor, Head of Department, Kh. Dosmukhamedov Atyrau University, Kazakhstan, e-mail: sabirovarysty@mail.ru, ORCID ID: https://orcid.org/0000-0002-9947-6564

Zhanat N. Yerniyazova - Candidate of Economic Sciences, Senior Lecturer, Korkyt Ata Kyzylorda University, Kazakhstan, e-mail: zhan-san@mail.ru, ORCID ID: https://orcid.org/0000-0003-2198-39

Gulnar E. Talapbayeva - Candidate of Economic Sciences, Senior Lecturer, Korkyt Ata Kyzylorda University, Kazakhstan, e-mail: gulnar.7575@mail.ru, ORCID ID: https://orcid.org/0000-0001-5162-6028

Aigul K. Masalimova - Master, Senior Lecturer Kh. Dosmukhamedov Atyrau University, Kazakhstan, e-mail: bikosh09@mail.ru, ORCID ID: https://orcid.org/0000-0001-7885-5736

Svetlana O. Kurmasheva - Master, Senior Lecturer Kh. Dosmukhamedov Atyrau University, Kazakhstan, e-mail: s.kurmasheva@asu.edu.kz, ORCID ID: https://orcid.org/ 0000-0001-9440-8450

\section{Авторлар туралы мәліметтер}

*Сабирова Рысты Куандиковна - экономика ғылымдарының кандидаты, қауымдастырылған профессор, «Х.Досмұхамедов атындағы Атырау университеті» КеАҚ, Қазақстан, e-mail: sabirovarysty@mail.ru, ORCID ID: https://orcid.org/0000-0002-9947-6564

Ерниязова Жанат Нурахметовна - экономика ғылымдарының кандидаты, аға оқытушы, Қорқыт Ата атындағы Қызылорда университеті, Қазақстан, e-mail: zhan-san@mail.ru, ORCID ID: https://orcid.org/00000003-2198-3985

Талапбаева Гүлнар Еділқызы - экономика ғылымдарының кандидаты, аға оқытушы, Қорқыт Ата атындағы Қызылорда университеті, Қазақстан, e-mail: gulnar.7575@mail.ru, ORCID ID: https://orcid.org/0000-0001-51626028

Масалимова Айгуль Канаткалиевна - магистр, аға оқытушы, «Х.Досмұхамедов атындағы Атырау университеті» КеАҚ, Қазақстан, е-mail: bikosh09@mail.ru, ORCID ID: https://orcid.org/0000-0001-7885-5736

Курмашева Светлана Олеговна - магистр, аға оқытушы, «Х.Досмұхамедов атындағы Атырау университеті» КеАҚ, Қазақстан, e-mail: s.kurmasheva@asu.edu.kz, ORCID ID: https://orcid.org/ 0000-0001-9440-8450

\section{Сведения об авторах}

* Сабирова Рысты Куандиковна - кандидат экономических наук, ассоцированный профессор, заведующая кафедрой, НАО «Атырауский университет им. Х.Досмухамедова, Казахстан, e-mail: sabirovarysty@mail.ru, ORCID ID: https://orcid.org/0000-0002-9947-6564

Ерниязова Жанат Нурахметовна - кандидат экономических наук, старший преподаватель, Кызылординский университет им.Коркыт Ата, Казахстан, e-mail: zhan-san@mail.ru, ORCID ID: https://orcid.org/0000-0003-219839

Талапбаева Гульнар Едиловна- кандидат экономических наук, старший преподаватель, Кызылординский университет им.Коркыт Ата, e-mail: gulnar.7575@mail.ru, ORCID ID: https://orcid.org/0000-0001-5162-6028

Масалимова Айгуль Канаткалиевна - магистр, преподаватель, НАО «Атырауский университет имени Х.Досмухамедова, Казахстан, e-mail: bikosh09@mail.ru, ORCID ID: https://orcid.org/0000-0001-7885-5736

Курмашева Светлана Олеговна - магистр, преподаватель, НАО «Атырауский университет им. Х.Досмухамедова, Казахстан, e-mail: s.kurmasheva@asu.edu.kz, ORCID ID: https://orcid.org/ 0000-0001-94408450 